\title{
KEAKURATAN MATERI TEKS ANEKDOT DALAM BUKU TEKS BAHASA INDONESIA SMA KELAS X
}

\author{
PUTRI OCVTAVIANI'LAILI ETIKA RAHMAWATI ${ }^{2}$ \\ Universitas Muhammadiyah Surakarta \\ A30II50I64@stydent.ums.ac.id'Laili.Rahmawati@gmail.com²
}

Pertama Diterima: 8 Juli 2019

Bukti Akhir Diterima: 24 September 2019

\begin{abstract}
Abstrak
Masalah yang diuji dalam penelitian ini adalah keakuratan materi dalam buku teks bahasa Indonesia SMA kelas X Kurikulum 2013. Banyaknya buku teks yang ada sekarang ini, membuat guru dapat memilih buku ajar sebagai salah satu bahan ajar yang digunakan oleh guru. Dan kemudahan itu sering menjadi pilihan yang kurang tepat. Pada saat ini banyak ditemukan materi yang tidak sesuai dan kurang mendukung tercapainya kompetensi yang ditentukan dalam kurikulum. Penelitian ini termasuk dalam penelitian kualitatif. Metode penelitian dalam penelitian ini menggunakan metode deskriptif kualitatif. Tujuan penelitian ini adalah mendeskripsikan keakuratan materi dalam buku teks bahasa Indonesia SMA kelas X Kurikulum 2013. Hasil penelitian ini menunjukkan bahwa keakuratan materi buku teks Bahasa Indonesia SMA kelas X kurikulum 2013 terbitan Erlangga dapat dikatakan cukup memenuhi syarat aspek keakuratan materi buku teks menurut standar kelayakan isi BNSP. Beberapa kekurangan yang ditemukan dalam buku teks ini antara lain: (1) belum menyajikan "Peta Kompetensi" yang mengandung prinsipprinsip yang digunakan siswa sebagai acuan untuk mencapai tujuan pembelajaran dan memahami materi pada masing-masing bab agar materi yang disampaikan dapat terstruktur dengan baik. (2) penyajian contoh yang kurang relevan yang berkaitan dengan karakteristik latar belakang dan status sosial, adanya unsur sara, dan tidak sesuai kebutuhan.
\end{abstract}

Kata Kunci: buku teks, keakuratan materi, kurikulum 2013.

\begin{abstract}
The problem tested in this study is the accuracy of the material in Indosnesia high school textbooks ini class X Curriculum 2013. The number of textbooks available today makes teachers able to choose textbooks as one of the teaching materials used by teachers. And convenience is often the wrong choice. At this time there are many material that are not suitable and do not support the achievement of the competencies specified in the curriculum. This research is included in qualitative research. The research method in this study used a qualitatuve descriptive method. The purpose of this study is to describe the accuracy of the material in Indonesian high school textbooks in class X 2013 curriculum. The results of this study indicate that the accuracy of Indonesian textbooks high school class X 2013 curriculum published by Erlangga can adequately meet the requirements of the accuracy of the textbooks content of BNSP. Some of the shortcomings found in this textbook include: (1) it has not presented a "Competency Map" which contains the principles students use as a reference to achieve learning objectives and understand the material in each chapter so that the material delivered can be well structured. (2) the presentation of less relevant examples relating to the characteristics of background and social status, the existence of elements of sara, and not as needed.
\end{abstract}

Keywords: textbooks, material accuracy, 2013 curriculum. 


\section{PENDAHULUAN}

Buku teks pelajaran merupakan salah satu sarana dan prasarana pendidikan yang penyusunan dan penulisannya harus mengacu pada tujuan pendidikan nasional, tujuan satuan pendidikan, standar isi, standar proses, standar kompetensi lulusan, dan standar sarana dan prasarana. Buku teks yang baik adalah buku teks yang berkualitas.

Adapun buku teks yang berkualitas harus memenuhi kriteria: a) Menarik minat peserta didik yang menggunakannya, b) Mampu memberikan motivasi belajar peserta didik yang menggunakannya, c) Memuat ilustrasi yang menarik hati peserta didik, d) Mempertimbangkan aspek-aspek linguistik sehingga sesuai dengan kemampuan peserta didik yang menggunakannya, e) Dapat merangsang aktivitasaktivitas pribadi pesrta didik, f) Mempunyai sudut pandang yang jelas dan tegas, sehingga tidak membingungkan pesrta didik yang menggunakannya, g) Mampu memberi pemantapan, penekanan materi pada para penggunanya.

Buku teks merupakan salah satu bahan ajar yang digunakan oleh guru dan berfungsi sebagai sumber belajar dan media yang mendukung tercapainya kompetensi yang menjadi tujuan pembelajaran. Banyaknya buku teks yang ada sekarang ini, membuat guru dapat memilih buku ajar yang tepat sebagai salah satu bahan ajar yang digunakan oleh guru. Banyaknya pilihan buku teks sekarang ini memudahkan guru untuk menentukan buku teks yang tepat digunakan sekolah untuk menjadi buku pendamping selain buku siswa yang diterbitkan oleh pemerintah.

Namun, sering kemudahan itu berbuah menjadi pilihan yang kurang tepat. Kondisi penulis yang kurang mengetahui dan memahami bagaimana cara menulis buku teks yang baik, bagaimana cara mengembangkan isi buku teks pelajaran dengan mempertimbangkan bahasa dan teknik penyajian yang memudahkan dan memotivasi siswa untuk belajar. Buku teks kebanyakan tidak disusun dan ditulis oleh pakar yang ahli dalam mata pelajaran tersebut. Didukung dengan kurangnya perhatian penerbit pada uji lolos seleksi kelayakan buku sesuai standar yang berlaku yakni Badan Standar Nasional Pendidikan (BSNP). Dari permasalahan-permasalahan itu besar kemungkinan banyak buku ajar yang kurang layak digunakan guru dan peserta didik dalam proses pembelajaran karena tidak sesuai dengan kelayakan buku ajar Bahasa Indonesia yang ditentukan oleh BSNP.

Pemilihan buku teks perlu mempertimbangkan berbagai hal diantaranya yang utama adalah adanya keunggulan buku teks sebagai sumber informasi, maupun pemberi rangsangan saat diperlukan mengingat penyajian materi tertentu dapat mempengaruhi sikap pembaca. Kemutakhiran tahun terbit juga dipertimbangkan dalam pemilihan akan tetapi yang lebih utama adalah data, dan isi dari buku teks tersebut.

Kritik terhadap buku teks Bahasa Indonesia Kurikulum 2013 memang dirasa lebih kencang daripada kritik terhadap BSE (Buku Sekolah Elektronik) yang merupakan bahan ajar dari KTSP (Kurikulum Tingkat Satuan Pendidikan). KTSP merupakan perbaikan dari kurikulum sebelumnya, yaitu KBK, sehingga buku teks dari KTSP lebih matang daripada buku teks Kurikulum 2013.

Pada awal kemunculannya, buku teks Kurikulum 2013 mendapatkan banyak kritik yang ditampilkan dalam media massa, seperti koran atau media online. Kritikan tersebut mengarah kepada buku teks yang dirasa belum matang dari aspek kebahasaan, isi, penyajian, dan kegrafikaan. 
Kritikan tersebut semakin terbukti kebenarannya ketika pihak guru dan siswa ikut memberikan kritik terhadap buku teks Kurikulum 2013, khususnya buku teks Bahasa Indonesia.

Meski kritikan terhadap buku teks Kurikulum 2013 tampak gencar, hal tersebut semata-mata demi perbaikan kualitas pendidikan di Indonesia. Guru dan praktisi pendidikan mengharapkan agar pemerintah mematangkan terlebih dahulu buku teks Kurikulum 2013, salah satunya dengan cara memperbaiki buku teks Kurikulum 2013. Apabila perbaikan tersebut dapat dilakukan, buku teks Kurikulum 2013 akan diterima dengan baik oleh guru dan siswa.

Sebuah buku teks pelajaran yang baik akan menggunakan bentuk kebahasaan yang sesuai dengan tingkat perkembangan siswa. Artinya, jika sebuah buku teks pelajaran itu digunakan oleh siswa, maka penulis harus yakin bahwa bacaan yang ada dalam buku tersebut memiliki tingkat keterbacaan yang sesuai dengan tingkat keterbacaan dan psikologi siswa. Selain aspek kebahasaan, penyajian, dan kegrafikaan, secara spesifik, salah satu hal yang perlu diperhatikan adalah aspek materi buku teks. Keakuratan materi buku ajar Bahasa Indonesia SMA kelas X perlu diteliti agar dapat mengetahui kesesuaian antara materi buku ajar dengan pemahaman siswa SMA kelas X.

Penelitian tentang buku teks telah dilakukan oleh peneliti terdahulu, di antaranya adalah (1) Banowati (2007) yang meneliti tentang bagaimana kualitas buku teks yang digunakan dalam pembelajaran Geografi di SMA di Kota Semarang; (2) Yusfiani dan Manihar (2011) yang meneliti tentang pengembangan dan Standarisasi Buku Ajar Kimia SMA/SMK Kelas XII Semester I Berdasarkan Standar Isi KTSP; (3) Rahmawati, et al (2013) yang meneliti tentang kelayakan buku saku IPA terpadu bilingual tema bahan kimia dalam kehidupan sebagai bahan ajar di MTs; (4) Jatmika (2014) yang meneliti tingkat kelayakan isi pada buku teks.

Penelitian-penelitian tersebut menunjukkan bahwa penelitian berkaitan dengan keakuratan buku teks masih belum banyak dilakukan oleh peneliti sebelumnya. Berdasarkan hal tersebut maka penelitian keakuratan buku teks sangat dibutuhkan. berdasarkan latar belakang tersebut akan dilakukan pengkajian secara mendalam terkait kesesuaian materi teks anekdot dan prosedur kompleks yang terdapat pada buku teks bahasa Indonesia kelas X Kurikulum 2013.

\section{Buku Teks}

Buku teks adalah buku pegangan peserta didik yang disertai dengan materi pembelajaran lain yang mendukung, yang sengaja disusun oleh para ahli di bidang pendidikan dan bahasa untuk disampaikan kepada peserta didik untuk mencapai tujuan pembelajaran tertentu, pada kelas tertentu dan dalam jangka waktu tertentu pula, Al-Ghazali dalam Yuli Yanti (2016:180).

Tarigan (2009:14) menyatakan bahwa buku teks adalah sama dengan buku pelajaran. Secara lebih lengkap buku teks adalah buku pelajaran dalam bidang studi tertentu yang merupakan buku standar, yang disusun oleh para pakar dalam bidang itu dengant maksud-maksud dan tujuan instruksional, yang diperlengkapi dengan sarana-sarana pengajaran yang serasi dan mudah dipahami oleh pemakainya di sekolah-sekolah dan perguruan tinggi sehingga dapat menunjang pembelajaran.

Berdasarkan pemaparn diatas, maka dapat disimpulkan bahawa buku teks adalah sebuah buku pelajaran dalam bidang studi tertentu yang disusun oleh para pakar sesuai dengan 
kurikulum, dirancang untuk penggunaan di kelas, yang digunakan untuk menunjang suatu program pengajaran dan diperlengkapi dengan sarana-sarana pengajaran yang sesuai dan serasi.

Muslimin (2011:88) menyatakan bahwa dari sudut pandang kebijakan pendidikan, diungkapkan dalam Peraturan Pemerintah Nomor 19 Tahun 2005 tentang Standar Nasional Pendidikan bahwa buku teks pelajaran termasuk ke dalam sarana pendidikan yang perlu diatur standar mutunya, sebagaimana juga standar mutu pendidikan lainnya, yaitu standar isi, standar proses, standar kompetensi lulusan, standar pendidikan dan kependidikan, standar sarana dan prasarana, standar pengelolaan, standar pembiayaan, dan standar penilaian pendidikan. Sitepu (2012:78-80) mengemukakan bahwa dalam penulisan buku teks pelajaran dalam setiap isi bab hendaknya mengandung empat unsur pokok, yaitu pengantar, isi pokok bahasan, penilaian, dan rangkuman.

Penulisan buku teks yang baik tidaklah mudah, mengingat peranan buku teks amatlah besar, seperti yang diungkapkan oleh Greene dan Petty dalam Banowati (2007:148), yaitu dapat: 1) mencerminkan sudut pandang yang tangguh dan moderen mengenai proses mengajar serta mendemonstrasikan aplikasinya dalam bahan pengajaran yang disajikan. 2) menyajikan suatu sumber pokok masalah yang kaya, mudah di baca dan bervariasi, yang sesuai dengan minat dan kebutuhan peserta didik, sebagai dasar bagi program-program kegiatan yang disarankan di mana keterampilan ekspresional dapat diperoleh melalui kondisi yang menyerupai kehidupan yang sebenarnya. 3) menyediakan suatu sumber yang tersusun rapi dan bertahap mengenai berbagai keterampilan eksponensial yang mengemban masalah pokok dalam komunikasi. 4) menyajikan secara bersama-sama dengan buku manual yang mendampingi metode dan sarana pengajaran untuk memotivasi peserta didik. 5) menyajikan fiksasi awal yang menunjang latihan-latihan dan tugas praktis. 6) menyajikan bahan atau sarana evaluasi dan remidial yang serasi dan tepat guna.

Untuk mengetahui apakah suatu buku teks dinyatakan layak digunakan untuk suber belajar peserta didik, Tarigan (2009: 22) mengemukakan pedoman penilaian buku teks sebagai berikut: (1) sudut pandang, buku harus memiliki landasan, prinsip, dan sudut pendang tertentu yang melandasi buku teks secara keseluruhan, (2) kenjelasan konsep, kejelasan kosep dalam buku teks haruslah jelas dan tandas, (3) relevan dengan kurikulum, (4) menarik minat, (5) menumbuhkan motivasi, (6) menstimulasi aktivitas siswa, (7) ilustratif, (8) buku teks harus dimengerti oleh pemakainya, (9) menunjang mata pelajaran lain, (10) menghargai perbedaan individu, (11) memantapkan nilai-nilai.

\section{Keakuratan Materi}

Materi mempunyai arti sesuatu yang menjadi bahan untuk diujikan, dibicarakan, dikarang, dianalisis dan sebagainya. Materi yang terdapat dalam buku teks memuat penjelasan terkait dengan konsep, definisi, prinsip, prosedur, contoh, dan pelatihan agar siswa dapat mengenali gagasan atau ide, mengidentifikasi gagasan, menjelaskan ciri suatu konsep atau gagasan, dapat mendefinisikan, menyusun formula/rumus/aturan, mengkonstruksi pengetahuan baru, dan menerapkan pengetahuan baru, dan merapkan pengatahuan sesuai dengan KI dan KD yang telah dirumuskan.Dalam hal keakuratan materi, ada 5 indikator yang harus diperhatikan yaitu (1) akurasi konsep dan definisi; (2) akurasi prinsip; (3) akurasi prosedur; (4) akurasi contoh, fakta, dan ilistrasi; (5) akurasi sosial, Muslich (2010:292). 


\section{Akurasi konsep dan definisi}

Materi dalam buku teks harus disajikan secara akurat untuk menghindari miskonsepsi yang dilakukan siswa. Konsep dan definisi harus dirumuskan dengan tepat untuk mendukung tercapainya KI dan KD. Konsep yang digunakan dalam buku teks harus jelas dan tandas. Keremang-remangan dan keamanan perlu dihindari agar siswa atau pembaca juga jelas pengertian, pemahaman, dan penangkapannya, Tarigan (2009:22).

Menurut Rosser dalam Susanti (2013), konsep adalah suatu abstraksi yang mewakili satu kelas objek-objek, kejadian-kejadian, atau hubungan-hubungan, yang mempunyai atributatribut yang sama. Konsep merupakan batu untuk membangun berpikir, dalam proses pembelajaran, hasil akhir yang akan dicapai adalah siswa memahami konsep-konsep yang disampaikan oleh guru. Jadi, pemahaman konsep memberi pengertian bahwa konsep-konsep yang diajarkan kepada peserta didik bukan merupakan hafalan saja, akan tetapi konsep-konsep tersebut harus benar-benar dipahami sehingga peserta didik dapat memecahkan masalahmasalah yang dihadapi berdasarkan konsep-konsep yang telah dipelajari oleh peserta didik tersebut, Susanti (2013).

Konsep, yaitu segala yang berwujud pengertian baru yang bisa timbul sebagai hasil pemikiran, yang meliputi definisi, pengertian, ciri khusus, hakikat, inti atau isi, dan sebagainya, Arsanti (2018). Konsep dalam buku teks dapat ditampilkan dalam uraian atau contoh. Hal ini dimaksudkan untuk membantu siswa dalam membangun jaringan pengetahuan yang utuh. Selain itu perlu juga ditunjukkan keterkaitan antara pelajaran satu dan pelajaran lain atau keterkaitan antara materi yang sedang dipelajari dan kehidupan sehari-hari agar siswa menyadari manfaat materi tersebut dalam kehidupan. Kemudian materi yang terdapat pada buku teks harus sesuai dengan perkembangan ilmu dan teknologi.

Muslich (2010:196) menyatakan bahwa keterkaitan antar konsep keterkaitan dalam buku teks dapat dimunculkan dalam uaraian atau contoh. Hal ini dimaksudkan untuk membantu siswa dalam membangun jaringan pengetahuan yang utuh. Selain itu perlu juga ditunjukkan keterkaitan antara pelajaran satu dengan pelajaran lain, atau keterkaitan antara materi yang sedang dipelajari dan kehidupan sehari-hari agar siswa menyadari manfaat materi tersebut dalam kehidupan. Sedangkan Kinanti dan Sudirman (2017:343) menyatakan bahwa keterkaitan antar konsep dibuktikan dengan uraian atau contoh yang terseji di dalam buku teks. Tujuannya untuk membantu peserta didik mengkonstruksi pengetahuan yang baru dan utuh. Serta konsep ini berkaitan dengan mata pelajaran sosiologi

2. Akurasi prinsip

Prinsip yang merupakan salah satu aspek yang digunakan untuk menyusun suatu teori. Prinsip-prinsip yang tersaji dalam buku teks perlu dirumuskan secara akurat agar tidak menimbulkan multi tafsir bagi siswa. Prinsip-prinsip yang disajikan mengisyaratkan kepada guru dan siswa yang menggunakannya agar mengetahui apa yang ingin dicapainya, Tarigan (2009: 60). Prinsip menurut Arsanti (2018:75) yaitu berupa hal-hal utama, pokok dan memiliki posisi penting, meliputi detail, rumus, adagum, postulat, paradigma, teorema, serta hubungan antar konsep yang mampu menggambarkan sebab dan akibat. 
Mursini (2012: 4) menyatakan bahwa terdapat tiga prinsip dalam penysunan buku teks yaitu (1) Prinsip Relevan artinya keterkaitan, materi yang ditulis hendaknya relevan dengan pencapaian KI/KD yang ingin dicapai. (2) Prinsip konsistensi artinya keajegan, jika kompetensi dasar yang harus dikuasai siswa empat macam, maka bahan ajar yang harus diajarkan juga harus meliputi empat macam keterampilan. (3) Prinsip kecakupan artinya materi yang diajarkan hendaknya cukup memadai dalam membantu siswa menguasai kompetensi dasar yang diajarkan. Bahkan tidak boleh terlalu sedikit, dan tidak boleh terlalu banyak. Apabila terlalu sediit akan kurang membantu dalam mencapai standar kompetensi dan kompetensi dasar. Sebaliknya, jika terlalu banyak akan membuang-buang waktu dan tenaga yang tidak perlu untuk mempelajarinya.

3. Akurasi prosedur

Menurut Beslina (2016:78) prosedur merupakan langkah-langkah yang harus dilakukan untuk mencapai suatu sasaran tertentu. prosedur harus dirumuskan secara akurat sehingga siswa tidak melakukan kekeliruan secara sistematis. Arsanti (2018:75) menyatakan bahwa prosedur merupakan langkah-langkah sistematis atau berurutan dalam mengerjakan sesuatu aktivitas dan kronologi suatu sistem.

4. Akurasi contoh, fakta, dan ilustrasi

Konsep, prinsip, prosedur, atau rumus harus diperjelas dengan contoh, fakta, dan ilustrai yang disajikan secara akurat. Buku teks hendaknya memuat gambar, foto, sketsa, cerita sejarah, contoh, atau soal-soal menarik yang dapat menimbulkan minat siswa untuk mengkaji lebih jauh. Apabila siswa tertarik terhadap materi yang dipelajari, ia akan terangsang untuk mempelajarinya secara jauh. Dengan cara dipaparkannya contoh, gambar, foto, dan cerita, siswa tidak hanya memahami suatu pengetahuan secara verbalistis, Beslina (2016).

a. Contoh

Muslich (2010:296) menyatakan bahwa materi yang tersaji dalam buku teks baiknya menghadirkan contoh latihan untuk mengemukakan gagasan peserta didik berkaitan dengan materi yang sudah dipelajari, baik secara tertulis maupun lisan. Contoh adalah benda, ilustrasi, angka, gambar dan lain-lain yang mendukung suatu konsep yang disajikan. Contoh bertujuan untuk memantapkan pemahaman pembaca tentang fakta atau data, konsep, prinsip, generalisasi, hukum, teori, nilai, prosedur, ketermapilan dan masalah. Prinsip yang menyajikan contoh hendaknya: (a) relevan dengan isi uraian, (b) konsistensi istilah, konsep, dalil, dan peran, (c) jumlah dan jenisnya memadai, (d) logis atau masuk akal, (e) sesuai dengan realitas, (f) dan bermakna, Sungkono (2003).

\section{b. Fakta}

Fakta menurut Arsanti (2018:74) yaitu segala hal yang berwujud kenyataan dan kebenaran, meliputi nama-nama objek, peristiwa sejarah, lambang, nama tempat, nama orang, nama bagian atau komponen suatu benda, dan sebagainya. 


\section{c. Ilustrasi}

Ilustrasi adalah sebuah citra yang dibentuk untuk memperjelas suatu informasi dengan memberi representasi secara visual. Esensi dari ilustrasi adalah pemikiran, ide,dan konsep yang melandasi apa yang ingin dijelaskan melalui gambar. Menghidupkan dan memberi bentuk visual dari sebuah tulisan adalah peran dari isulator. Secara umum ilustrasi adalah intruksi yang baik, informasi dapat lebih mudah untuk dicerna ketika disampaikan secara visual, Witabora dalam Muslich (2010:196) menyatakan bahwa materi dalam buku teks hendaknya memuat uraian, strategi, gambar, foto, sketsa, serita sejarah, contoh, atau soal-soal menarik yang dapat menimbukan minat siswa untuk mengkaji lebih jauh. Apabila siswa tertarik pada materi yang dipelajari, ia akan terangsang untuk mempelajarinya lebih jauh.

5. Akurasi sosial

Penguasaan siswa atas konsep, prinsip, prosedur, atau algoritma harus dibangun oleh soalsoal yang disajikan secara akurat, Beslina (2016). Soal-soal yang disajikan disusun untuk menumbuhkan kebulatan pemahaman atau keterampilan dalam suatu mata pelajaran. Tugas dan pelatihan juga harus memperhatikan perbedaan individu, Tarigan (2009:61).

Muslich (2010:195) menyatakan bahwa materi dalam buku teks hendaknya memuat contoh, soal-soal latihan yang berkaitan dengan topik yang dibicarakan sehingga sajian materinya lebih luas dan lebih dalam daripada materi yang dituntut $\mathrm{KD}$, serta menjelaskan penerapan suatu konsep dalam kehidupan sehari-hari. Hal ini dimaksudkan agar siswa mampu menerapkan setiap konsep yang dipelajari dalam kehidupan nyata. Serta untuk mengkomunikasikan gagasan, baik secara tertulis maupun lisan, untuk memperjelas keadaan atau masalah yang sedang dipelajari atau dihadapi. Dengan soal-soal latihan ini, diharapkan mampu mendorong siswa memperoleh informasi lebih lanjut dari berbagai sumber lain dan diharapkan siswa mempunyai kompetensi yang lebih luas dan kaya.

\section{METODE PENELITIAN}

Penelitian ini termasuk dalam penelitian kualitatif, sebagaimana diungkapkan oleh Sugiyono dalam Rohmadi dan Yakub (2017: 23) menurutnya metode penelitian kualitatif adalah metode penelitian yang berlandaskan pada filsafat postpositivisme, digunakan untuk meneliti pada kondisi objek yang alamiah (lawannya adalah eksperimen) dengan peneliti sebagai instrumen kunci, dan hasil penelitian kualitatif lebih menekankan makna daripada generalisasi.

Analisis data dalam proposal skripsi ini bersifat induktif atau kualitatif. Hasil dari analisis induktif ini sebenarnya adalah mengembangkan kategori ke dalam sebuah model atau kerangka yang dapat meringkas data mentah yang kompleks. Analisa secara induktif merupakan prosedur untuk menemukan konsep, tema, ataupun model berdasarkan interpretasi analisis ataupun peneliti melalui pembacaan yang detail terhadap teks, Rumat (2017:4-5). Pengambilan sampel dan sumber data dilakukan secara purposive dan snowball, teknik pengumpulan data yang digunakan adalah trianggulasi data. Dan jenis penelitian ini adalah deskriptif kualitatif. 
Adapun jenis data yang digunakan dalam penulisan proposal skripsi ini adalah data kulitatif, yakni data yang diperoleh berupa ketidakakuratan konsep, definisi, contoh, fakta, dan ilustrasi dalam buku teks bahasa Indonesia Kulikulum 2013. Sumber data yang digunakan adalah buku teks bahasa Indonesia Kurikulum 2013 karya Sobandi terbitan Erlangga.

Teknik pengumpulan data dalam penelitian ini adalah study dokumenter dan kajian pustaka. Study dokumenter merupakan teknik pengumpulan data dengan mengumpulkan dan menganalisis dokumen yang diperlukan sebagai data informasi, baik berupa dokumen tertulis, gambar, maupun elektronik. Dalam penelitian ini jenis studi dokumenter yang diteliti berupa dokumen tertulis, yakni buku teks bahasa indonesia SMA kelas X kurikulum 2013. Kajian pustaka digunakan untuk melihat penelitian terdahulu dan teori yang relevan dengan penelitian ini.

Teknik pemeriksaan keabsahan data yang digunakan dalam penelitian ini adalah trianggulasi. Trianggulasi adalah suatu pendekatan analisa data dengan memanfaatkan berbagai sumber untuk keperluan pengecekan atau sebagai pembanding terhadap data yang telah diperoleh. Trianggulasi pada prinsipnya merupakan suatu model pengecekan data untuk menentukan apakah data yang telah diperoleh benar-benar tepat menggambarkan fenomena pada sebuah penelitian, Bachri (2010:57).

Analisis data yang digunakan dalam penelitian ini adalah analisis doamin. Analisis domain digunakan untuk menganalisis gambaran objek penelitian secara umum atau tingkat permukaan, namun relatif utuh tentang objek penelitian tersebut. Teknik ini biasanya digunakan dalam penelitian eksplorasi. Artinya hasil penelitian ini hanya ditargetkan untuk memperoleh gambaran seutuhnyadari objek yang diteliti, tanpa harus diperinci secara detail unsur-unsur yang ada dalam keutuhan objek penelitian tersebut.

\section{HASIL PENELITIAN DAN PEMBAHASAN}

\section{Hasil Penelitian}

\section{Akurasi Konsep dan Definisi}

Materi dalam buku teks harus disajikan secara akurat untuk menghindari miskonsepsi yang dilakukan siswa. Konsep dan definisi harus dirumuskan dengan tepat (well defined) untuk mendukung tercapainya KI dan KD. Pada materi teks anekdot dan teks prosedur kompleks dalam buku teks terbitan Erlangga yang dianalisis ini, materi telah disajikan secara akurat dan tidak menimbulkan miskonsepsi yang dilakukan siswa. Hal ini dapat kita lihat pada pada setiap materi yang ditampilkan pada bab yang menjelaskan teks anekdot dan teks prosedur kompleks. 
1. Teks Anekdot

\subsection{Memahami Struktur Dan Kaidah Teks Anekdot \\ Anekdot adalah cerita singkat yang fiktif dan lucu tentang pribadi seorang tokoh atau beberapa tokoh yang benar-benar ada.}

Struktur Anekdot (hal. 2)

1. Tokoh

Anekdot hanya menggunakan manusia sebagai tokoh, baik terkenal maupun tidak. Jumlahnya bisa beberapa;.....

2. Alur

Alur adalah rangkaian peristiwa atau urutan bagian-bagian dalam sebuah cerita.

3. Latar

Latar adalah segala keterangan yang berhubungan dengan waktu, tempat dan suasana yang tergambar dalam cerita.

Kaidah Anekdot (hal. 3)

1. Fiktif ....

2. Lucu ....

3. Pribadi Seorang Tokoh .... .

4. Mengandung Pesan ....

1.2 Menginterpretasi Makna Teks Anekdot

Interpretasi adalah pemberian kesan, pendapat, atau pandangan terhadap sesuatu. (hal. 4)

Data di atas menyajikan materi tentang teks anekdot, yang memaparkan definisi, struktur, kaidah teks anekdot, dan definisi interpretasi. Data diatas dinilai sudah relevan dan akurat karena sudah disajikan secara jelas dan tidak mengakibatkan miskonsepsi yang dapat dilakukan oleh siswa.

\section{Akurasi Prinsip}

Sebelum menginjak materi seharusnya terdapat halaman "Peta Kompetensi". Halaman "Peta Kompetensi" ini berisi peta konsep materi tiap bab yang berguna untuk mengetahui alur materi yang akan dipelajari, tujuan pembelajaran berisi tujuan yang harus dicapai setelah memahami materi pada setiap babnya, nilai karakter bangsa yang harus dikembangkan berisi nilai karakter yang harus selalu ada dalam setiap pembelajaran semua materi, dan kata kunci berupa kata-kata sukar yang awam untuk siswa. Pada halaman "Peta Kompetensi" mengandung prinsip-prinsip yang digunakan siswa sebagai acuan untuk memahami materi pada masing-masing bab agar materi yang disampaikan dapat terstruktur dengan baik. 
Kompetensi Dasar Teks Anekdot

\begin{tabular}{|l|}
\hline Kompetensi Dasar (halaman 1) \\
3.1 Memahami struktur dan kaidah teks anekdot, baik melalui lisan maupun \\
tulisan. \\
4.1 Menginterpretasi makna teks anekdot, baik melalui lisan maupun tulisan. \\
Kompetensi Dasar (halaman 11) \\
3.2 Membandingkan teks anekdot, baik secara lisan maupun tulisan. \\
4.2 Memproduksi teks anekdot, baik secara lisan maupun tulisan. \\
Kompetensi Dasar (halaman 23) \\
3.3 Menganalisis teks anekdot, baik melalui lisan maupun tulisan. \\
4.3 Menyunting teks anekdot sesuai dengan struktur dan kaidah teks, baik \\
secara lisan maupun tulisan \\
Kompetensi Dasar (halaman 33) \\
3.4 Mengidentifikasi teks anekdot, baik secara lisan maupun tulisan. \\
4.4 Mengabstraksi teks anekdot, baik secara lisan maupun tulisan. \\
Kompetensi Dasar (halaman 39) \\
3.5 Mengevaluasi teks anekdot berdasarkan kaidah teks, baik lisan maupun \\
tulisan. \\
4.5 Mengonversi teks anekdot ke dalam bentuk lain.
\end{tabular}

Data di atas menunjukkan kompetensi dasar dari bab 1-5 yang menyajikan materi teks anekdot, data di atas dinilai kurang akurat dan relevan karena belum terdapat peta kompetensi, tujuan pembelajaran, dan nilai karakter yang seharusnya terdapat pada awal bab.

\section{Akurasi Prosedur}

Prosedur merupakan langkah-langkah yang harus dilakukan untuk mencapai suatu sasaran tertentu. prosedur harus dirumuskan secara akurat sehingga siswa tidak melakukan kekeliruan secara sistematis.

Teks Anekdot

2.2 Membuat Teks Anekdot

Langkah membuat anekdot sama dengan menulis cerita lainnya, yaitu menentukan topik, mengumpulkan bahan, menyusun kerangka, mengembangkan kerangka, dan memberi judul.

1) Menentukan Topik

Tentukanlah anekdot apa yang akan dibuat, misalnya, tentang tokoh agama, tokoh politik, tokoh masyarakat, pejabat pemerintah, dosen, guru, dokter, penyuluh $\mathrm{KB}$, atau tokoh lainnya... .

2) Mengumpulkan Bahan

Topik dapat diperoleh dari berbagai sumber, seperti pengalama pribadi, pengalaman orang lain, pengamatan, surat kabar, siaran televisi, imajinasi, atau dari yang lainnya.

3) Menyusun Kerangka

Menyusun kerangka berarti memecahkan topik ke dalam beberapa subtopik secara sistematis dan logis. Susunannya dapat mengikuti pola: (1) eksposisiintrik-resolusi, (2) abstrak-orientasi-krisis-reaksi-koda, (3) perkenalan-isi 
cerita-akhir yang mengentak, atau pola yang lainnya.

4) Perhatikan penjelasan berikut.
a) Menegembangkan Kerangka
Setelah kerangka atau urutan subtopik tersusun, langkah selanjutnya adalah mengembangkan kerangka tersebut menjadi anekdot yang lengkap. ... .
b) Memberi Judul
Langkah berikutnya adalah memberi judul. .. .

Data di atas menyajikan langkah-langkah membuat teks anekdot. Langkah-langkah atau prosedur dalam menyusun teks anekdot di atas dipaparkan secara jelas dan runtut. Hal ini tentu dapat menghindarkan siswa untuk melakukan kesalahan sistematis pada materi membuat teks anekdot yang diajarkan dalam buku teks.

\section{Akurasi contoh, fakta, dan ilustrasi}

Konsep, prinsip, prosedur, atau rumus harus diperjelas oleh contoh, fakta, dan ilustrasi yang disajikan secara akurat. Dengan cara demikian, siswa tidak hanya memahami suatu pengetahuan secara verbalistis.

Perhatikan kutipan teks anekdot (1) berikut.

Pak Harto Lewat Jalan Tol
Suatu hari rombongan keluarga Presiden Soeharto dengan mobil
masing-masing memasuki gerbang jalan tol Jagorawi. Yang pertama
memasuki gerbang adalah Tutut. la membayar dengan pecahan 100.000-an.
Ketika akan diserahkan uang kembaliannya, ia menolak dan terus melaju
memasuki jalan tol.
Berikunya yang masuk ke gerbang tol adalah Bambang. la menyerahkan
uang pecahan 50.000-an. Ketika akan diserahkan uang kembaliannya, ia pun
menolak dan melaju ke jalan tol menyusul Tutut.
Selanjutnya, giliran Tommy masuk dan memberikan uang pecahan
20.000-an. Penjaga pintu tol pun memberikan uang kembaliannya. Namun,
seperti kakak-kakaknya, ia pun tidak mau menerima uang kembaliannya.
"Keep the changel" katanya enteng.
Terakhir yang masuk gerbang tol adalah Pak Harto. Beliau membayar
dengan uang pecahan 10.000-an. Si petugas tol berpikir bahwa Babe juga
pasti tidak akan menerima uang kembaliannya. Petugas itupun tidak
menyerahkan uang kembalian Pak Harto. Namun, mobil beliau tidak
bergeming, tetap berada di depan loket.
Melihat itu, si penjaga memberanikan diri bertanya kepada beliau.
"Kenapa, pak?"
"la, kembaliannya mana?"tanya Pak Harto.
"Lo, tadi anak-anak bapak: Tutut, Bambang, dan Mas Tommy meolak
kembaliannya. Makannya saya pikir bapak juga pasti akan menolak
kembaliannya," kata petugas tol.
"Enak saja, jangan bandingkan saya dengan mereka dong! Mereka kan
Harto diringi senyumnya yang khas.


Penyajian kutipan teks anekdot di atas merupakan implementasi KD 3.1 Memahami struktur dan kaidah teks anekdot. Data tersebut menyajikan teks anekdot Pak Harto Lewat Jalan Tol sebgai contoh. Materi ini dikatakan kurang relevan dengan syarat karakteristik yang berkaitan dengan latar belakang dan status sosial buadaya. Hal ini dikarenakan karakteristik sosial buku yang menjadi objek penelitian diperoleh di Kartasura, daerah yang jauh dari tol Jagorawi, meskipun contoh tersebut mampu membuat siswa menjadi mudah memahami bagaimana wujud teks anekdot tersebut. Tetapi kesesuaian ini belum dilengkapi dengan adanya ilustrasi peristiwa tentang teks anekdot di atas.

Membuat Teks Anekdot (hal. 14)

Contoh:

\begin{tabular}{|c|c|c|c|}
\hline \multicolumn{3}{|c|}{ Pola Pengembangan } & Urutan Kerangka \\
\hline Perkenalan & Eksposisi & Abstrak & $\begin{array}{l}\text { - Pada bulan ramadan, Gus Dur dan para kiai } \\
\text { diundang pak Harto ke kediamannya untuk } \\
\text { buka puasa bersama. }\end{array}$ \\
\hline \multirow[t]{2}{*}{ Isi } & Intrik & Orientasi & $\begin{array}{l}\text { - Pak harto meminta para kiai untuk salat } \\
\text { tarawih bersama di kediamannya. } \\
\text { - Gus Dur bertanya, tarawih akan mengikuti NU } \\
\text { lama atau NU baru. } \\
\text { - Pak Harto bingung dengan istilah NU lama } \\
\text { dan NU baru dan bertanya apa perbedaannya. } \\
\text { - Gus Dur menjelaskan bahwa NU lama } \\
\text { tarawihnya } 23 \text { rakaat. } \\
\text { - Pak Harto tidak kaget dan bersedia } \\
\text { melaksanakan tarawih } 23 \text { rakaat. }\end{array}$ \\
\hline & Konflik & Krisis & $\begin{array}{l}\text { - Namun, Pak Harto penasaran dengan istilah } \\
\text { NU baru dan NU baru dan meminta Gus Dur } \\
\text { menjelaskannya. }\end{array}$ \\
\hline \multirow[t]{2}{*}{$\begin{array}{l}\text { Akhir yang } \\
\text { mengentak }\end{array}$} & Resolusi & Reaksi & $\begin{array}{l}\text { - Gus Dur menjelaskan bahwa NU baru jumlah } \\
\text { tarawihnya diskon } 60 \% \text { jadi } 11 \text { rakaat. }\end{array}$ \\
\hline & & Koda & $\begin{array}{l}\text { - Pak Harto akhirnya memilik tarawih NU baru } \\
\text { alasannya pinggangnya sakit. } \\
\text { - Pak Harto, Gus Dur, para kiai, dan yang } \\
\text { lainnya tertawa bersama. }\end{array}$ \\
\hline
\end{tabular}

Data di atas merupakan imlementasi dari KD 4.2 Memproduksi teks anekdot. Data tersebut menyajikan contoh membuat kerangka teks anekdot yang dipaparkan secara jelas dan runtut. Sehingga data di atas mampu membuat siswa tidak mengalami keslahan sistematis pada materi membuat teks anekdot karena disajikan contohnya. Materi ini dinilai kurang relevan karena teks anekdot yang digunakan untuk contoh mengandung unsur sara. Akan lebih relevan apabila teks yang digunakan sebagai contoh adalah teks yang berkaitan dengan kehidupan sehari-hari siswa. 
Menganalisis Teks Anekdot (hal. 23)

Perhatikan kembali teks anekdot "Pak Harto Lewat Jalan Tol" dan berikut analisis teks tersebut.

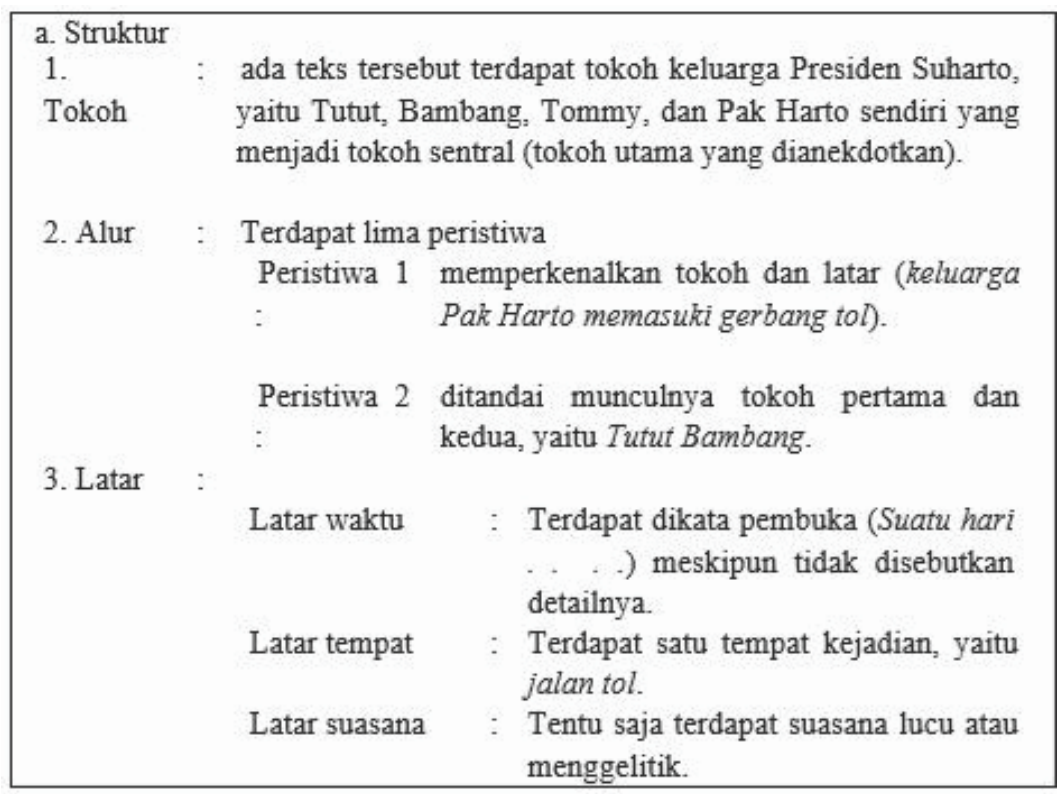

Data di atas menyajikan contoh analisis teks anekdot "Pak Harto Lewat Jalan Tol". Data diatas memudahkan siswa untuk memahami materi KD 3.3 Menganalisis teks anekdot, dan memudahkan siswa untuk melakukan analisis teks anekdot. Materi di atas dinyatakan kurang relevan karena teks anekdot yang digunakan mengandung unsur sara yang dapat menimbulkan perselisihan atau pernedaan antar individu.

Menyunting Teks Anekdot (hal. 24-25)

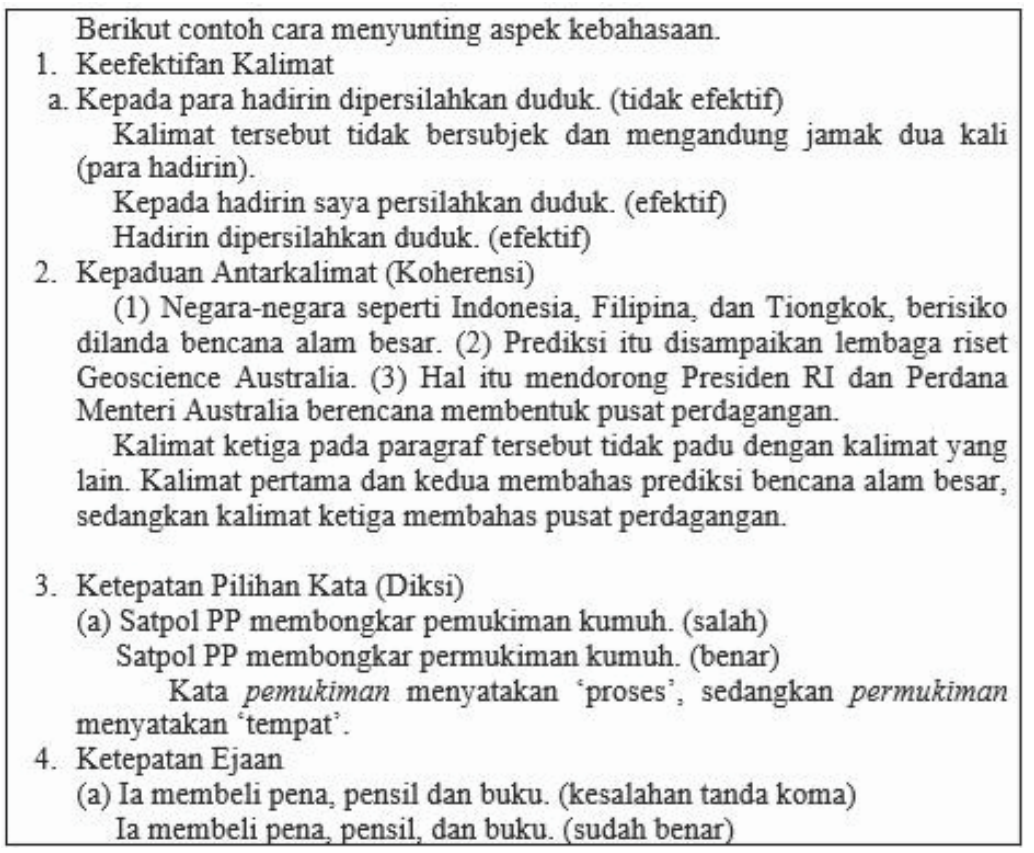

Data di atas merupakan implementasi dari KD 4.3 Menyunting teks anekdot sesuai dengan struktur dan kaidah teks. Data tersebut menyajikan contoh cara menyunting aspek kebahasaan. Materi ini dikatakan mendalam karena mampu membuat siswa tidak mengalami kesulitan pada 
materi menyunting teks anekdot karena telah menyajikan contoh yang disajikan secara jelas dan runtut. Data di atas menunjukkan akurasi antara contoh menyunting aspek kebahasaan dengan fakta yang berupa materi menyunting teks anekdot yang disajikan.

Mengabstraksi Teks Anekdot (hal. 33-34)

Perhatikan kembali teks anekdot yang berjudul "Pak Harto Memilih NU Diskon". Kita dapat membuat abstraksinya sebagai berikut.

Suatu hari di bulan Ramadhan di kediaman Pak Harto, setelah buka bersama dan salat maghrib, terjadilah obrolan antara Pak Harto dan Gus Dur. PakHarto meminta para kiai untuk tidak pulang dulu. Sebagai kepala kiai, Gus Dur bertanya bahwa salat tarawihnya mau mengikuti NU lama atau NU baru. Pak Harto merasa bingung dan penasaran lalu minta dijelaskan perbedaan tarawi NU lama dan NU baru. Gus Dur menjelaskan bahwa NU lama tarawihnya 23 Rekaat, sedangkan NU baru diskon $60 \%$ jadi tarawih dan witirnya tinggal 11 rakaat.

Data di atas merupakan implementasi dari KD 4.4 Mengabstraksi teks anekdot. Data tersebut menyajikan contoh abstraksi dari teks anekdot yang berjudul "Pak Harto Memilih NU Diskon". Penyajian contoh abstraksi dipaparkan secara jelas dan tidak membuat siswa mengalami kesulitan pada materi mengabstraksi teks anekdot yang disajikan pada buku teks terbitan Erlangga ini. Tetapi jika dianalisis secara mendalam data di atas dikatakan kurang relevan dan mendalam karena mengandung unsur sara.

Mengonversi Teks Anekdot (hal. 40-41)

Perhatikan contoh konversi anekdot "Pak Harto Pilih NU Diskon berikut".

\begin{tabular}{|c|c|}
\hline Teks Prosa & Teks Drama \\
\hline Pak Harto Pilih NU Diskon & Pak Harto Pilih NU Diskon \\
\hline \multirow[t]{3}{*}{$\begin{array}{l}\text { Suatu hari di bulan Ramadhan, Gus Dur } \\
\text { bersama beberapa kiai diundang ke kediaman } \\
\text { Presiden Suharto untuk buka bersama. Setelah } \\
\text { buka, diteruskan salat magrib berjamaah. } \\
\text { Setelah makan dan minum, terjadilah obrolan } \\
\text { antara pak Harto dan Gus Dur. } \\
\text { "Gus Dur, sampai malam di sini, kan?" tanya } \\
\text { Pak Harto. }\end{array}$} & $\begin{array}{l}\text { Suatu hari di bulan Ramadhan, Gus Dur } \\
\text { bersama beberapa kiai diundang ke } \\
\text { kediaman Presiden Suharto untuk buka } \\
\text { bersama. Setelah buka, diteruskan salat } \\
\text { magrib berjamaah. Setelah makan dan } \\
\text { minum, terjadilah obrolan antara pak Harto } \\
\text { dan Gus Dur. }\end{array}$ \\
\hline & $\begin{array}{l}\text { Pak Harto: Gus Dur, sampai malam di } \\
\text { sini, kan? }\end{array}$ \\
\hline & $\begin{array}{l}\text { Gus Dur : } \begin{array}{l}\text { Tidak, Pak! Saya harus } \\
\text { pergi ke tempat lain. }\end{array}\end{array}$ \\
\hline
\end{tabular}

Data di atas menyajikan kutipan contoh koncersi teks anekdot "Pak Harto Pilih NU Diskon". Akan tetapi teks anekdot yang digunakan dinilai kurang relevan karena mengandung unsur sara, akan lebih relevan jika siswa disajikan teks anekdot tentang pendidikan, atau kegiatan sehari-hari.

\section{Akurasi Sosial}

Penguasaan siswa atas konsep, prinsip, prosedur, atau algoritma harus dibangun oleh soal-soal yang disajikan secara akurat. 
Uji Kompetensi (halaman 9-10)

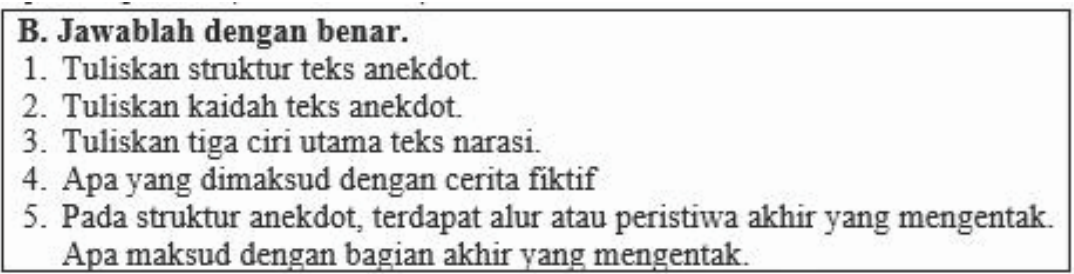

Pada bab 1 "Memahami dan Menginterpretasi Teks Anekdot" materi tentang teks anekdot ini ditunjang oleh individu. Dalam materi ini telah tercantum apa itu teks anekdot, bagaimana struktur dan kaidah teks anekdot. Semua materi yang disajikan secara detail dan lengkap dalam buku teks Erlangga ini. Hal ini juga didukung dengan adanya aktivitas tugas uji kompetensi yang dikerjakan secara individu yang dapat menunjang tingkat pemahaman siswa terhadap materi ini. Tetapi pada data di atas dinilai kurang relevan karena belum terdapat soal-soal yang mengasah kemampuan siswa tentang pemahaman materi menginterpretasi teks anekdot.

Uji Kompetensi (halaman 22)

B. Jawablah dengan benar.

1. Apa perbedaan antara teks anekdot dan lelucon?

2. Apa yang dimaksud dengan bagian akhir cerita yang mengentak?

3. Tentukanlah salah satu topik yang menurut kalian menarik untuk dijadikan anekdot. Uraikanlah topik tersebut menjadi beberapa sub topik.

4. Susunlah subtopik-subtopik tadi sehingga membentuk kerangka anekdot yang runtut dengan pola: abstrak-orientasi-krisis-reaksi-koda.

5. Kembangkanlah kerangka tersebut menjadi anekdot yang utuh

Pada bab 2 "Membandingkan dan Memproduksi Teks Anekdot" materi tentang teks anekdot ini hanya ditunjang uji kompetensi yang dikerjakan secara individu. Data di atas dinilai sudah relevan karena soal-soal yang disajikan sudah mampu mengasah tingkat pemahaman siswa yang mencakup materi membandingkan dan menginterpretasi teks anekdot.

Uji Kompetensi (halaman 31-32)

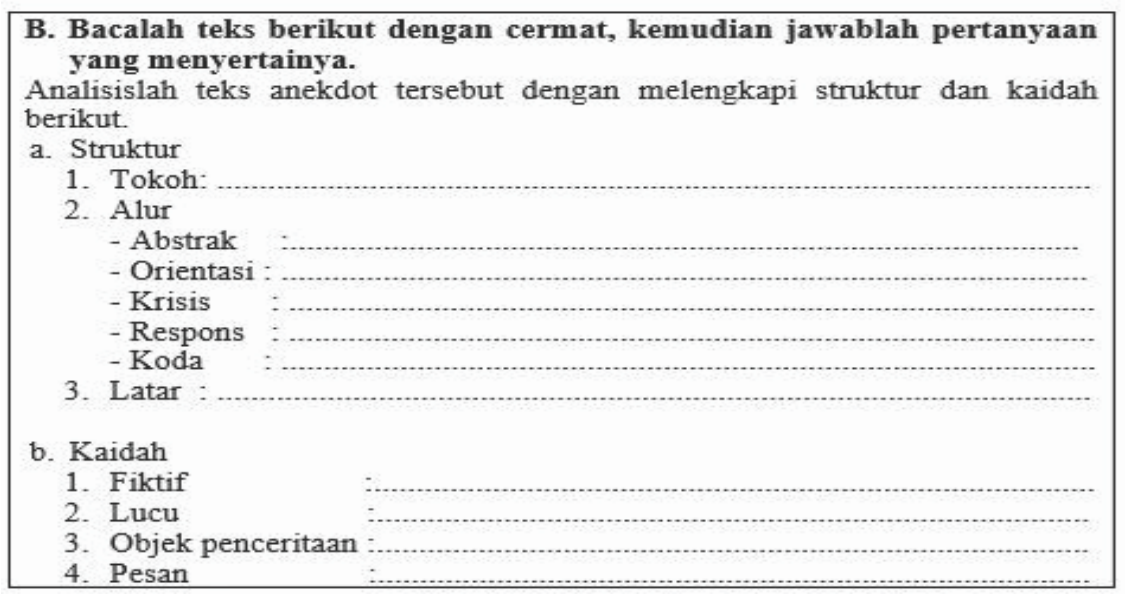

Pada bab 3 "Menganalisis dan Menyunting Teks Anekdot" materi tentang teks anekdot ini ditunjang oleh uji kompetensi yang berupa 20 soal pilihan ganda dan 5 soal esai yang dikerjakan 
secara individu. Data di atas dinilai kurang relevan karena belum mampu menunjang kemampuan siswa terhadap materi menyunting teks anekdot.

Uji Kompetensi (halaman 38)

B. Jawablah dengan benar.

1. Jelaskan apa yang dimaksud dengan mengabstraksi.

2. Tuliskan langkah-langkah mengabstraksi.

3. Jelaskan apa yang dimaksud dengan mengidentifikasi.

4. Sebutkan identitas struktur teks anekdot.

5. Sebutkan identitas kaidah teks anekdot.

Pada bab 4 "Mengidentifikasi dan Mengabstraksi Teks Anekdot" materi tentang teks anekdot. Data di atas dinilai kurang relevan karena belum menunjang pemahaman siswa tentang materi mengidentifikasi dan mengabstraksi teks anekdot, karena soal esai di atas belum melatih kemampuan siswa untuk mengidentifikasi dan megabstraksi teks anekdot. Data di atas akan lebih relevan apabila disajikan sebuah teks anekdot, kemudian siswa diminta untuk mengidentifikasi dan mengabstraksi teks yang telah disajikan, dengan begitu pengetahuan dan kemampuan siswa tentang materi yang disajikan dapat terasah.

Uji Kompetensi (halaman 46)

B. Bacalah teks berikut, kemudian jawablah pertanyaan yang
menyertainya.
1. Apakah teks tersebut termasuk teks anekdot?
2. Apakah teks tersebut memiliki struktur yang sama dengan anekdot?
3. Apakah teks tersebut memiliki kaidah yang sama dengan teks anekdot?
4. Apakah hubungan antar kalimatnya sudah padu?
5. Apakah teks tersebut menggunakan ejaan (tanda baca, huruf kapital, dan
penulisan kata baku) yang benar?

Pada bab 5 "Mengevaluasi dan Mengonversi Teks Anekdot" soal-soal yang disajikan di atas dinilai kurang relevan karena belum menunjang tingkat pemahaman dan kemampuan siswa tentang materi mengonversi teks anekdot yang disajikan.

\section{Pembahasan}

Berdasarkan hasil penelitian dan penelitian yang menjadi pijakan dalam penelitian ini, berikut perbandingan antara penelitian terdahulu dengan penelian ini.

Widodo, Handoyo Puji (2007) yang meneliti tentang "Textbook Analysis On Collage Academic Writing" hasil penelitiannya menunjukkan bahwa penulis mengungkapkan tujuan yang jelas dalam berorganisasi. Isi dalam buku teks berhubungan dengan pemakaian, contoh, latihan, dan tugas menulis yang mencerminkan keistimewaan teori menulis yang diperlukan mahasiswa. Sedangkan hasil penelitian saya ditemukan penyajian materi yang kurang akurat dengan menggunakan teori Siagian (2015: 78) materi yang kurang akurat tersebut (1) Belum menyajikan "Peta Kompetensi" yang mengandung prinsip-prinsip yang digunakan siswa sebagai acuan untuk mencapai tujuan pembelajaran dan memahami materi pada masing-masing bab agar materi yang disampaikan dapat terstruktur dengan baik. (2) Penyajian contoh yang kurang relevan yang berkaitan dengan karakteristik latar belakang dan status sosial, adanya unsur sara, dan tidak sesuai kebutuhan. (3) Belum tersedia ilustrasi. 
Nonaka, et al (2012) "Content Analysis of Primary and Secondary School Textbooks Regarding Malaria Control: A Multi-Country Study" hasil penelitiannya berupa "Textbooks rarely included knowledge and skills that are crucial to protect schoolchildren and their families from malaria. This study identified the need for improvement to textbook contents regarding malaria." Sedangkan hasil penelitian saya ditemukan penyajian materi yang kurang akurat dengan menggunakan teori Siagian (2015: 78) materi yang kurang akurat tersebut (1) Belum menyajikan "Peta Kompetensi" yang mengandung prinsip-prinsip yang digunakan siswa sebagai acuan untuk mencapai tujuan pembelajaran dan memahami materi pada masing-masing bab agar materi yang disampaikan dapat terstruktur dengan baik. (2) Penyajian contoh yang kurang relevan yang berkaitan dengan karakteristik latar belakang dan status sosial, adanya unsur sara, dan tidak sesuai kebutuhan. (3) Belum tersedia ilustrasi.

Hashemi (2012) "Textbook Evaluation: An Investigation into Touchstone Series" hasil penelitiannya berupa "Results indicated that Touchstone series was a suitable and appropriate device for language teachers to obtain their aims as well as the aims of the language institutes and that except for practical considerations of the books there was no statistically significant difference between the attitudes of male and female teachers towards the series. "Sedangkan hasil penelitian saya ditemukan penyajian materi yang kurang akurat dengan menggunakan teori Siagian (2015: 78) materi yang kurang akurat tersebut (1) Belum menyajikan "Peta Kompetensi" yang mengandung prinsip-prinsip yang digunakan siswa sebagai acuan untuk mencapai tujuan pembelajaran dan memahami materi pada masing-masing bab agar materi yang disampaikan dapat terstruktur dengan baik. (2) Penyajian contoh yang kurang relevan yang berkaitan dengan karakteristik latar belakang dan status sosial, adanya unsur sara, dan tidak sesuai kebutuhan. (3) Belum tersedia ilustrasi.

Nurmutia, et al (2013) yang meneliti tentang “Analisis Materi, Penyajian, dan Bahasa Buku Teks Matematika SMA Kelas X di Kabupaten Rembang” dari hasil penelitian dapat disimpulkan bahwa buku Matematika Jilid 1 untuk SMA Kelas X yang digunakan di Kabupaten Rembang sudah memenuhi standar aspek materi, penyajian, dan bahasa menurut BSNP serta sudah memuat materi pokok yang memenuhi ketiga standar aspek tersebut. Sedangkan hasil penelitian saya ditemukan penyajian materi yang kurang akurat dengan menggunakan teori Siagian (2015: 78) materi yang kurang akurat tersebut (1) Belum menyajikan "Peta Kompetensi" yang mengandung prinsip-prinsip yang digunakan siswa sebagai acuan untuk mencapai tujuan pembelajaran dan memahami materi pada masing-masing bab agar materi yang disampaikan dapat terstruktur dengan baik. (2) Penyajian contoh yang kurang relevan yang berkaitan dengan karakteristik latar belakang dan status sosial, adanya unsur sara, dan tidak sesuai kebutuhan. (3) Belum tersedia ilustrasi.

Kraenbring, et al (2014) “Accuracy and Completeness of Drug Information in Wikipedia: A Comparison with Standard Textbooks of Pharmacology" hasil penelitian berupa "Both Wikipedia and textbooks samples had comparable, low readability. Our study suggests that Wikipedia is an accurate and comprehensive source of drug-related information for undergraduate medical education. "Sedangkan hasil penelitian saya ditemukan penyajian materi yang kurang akurat dengan menggunakan teori Siagian (2015: 78) materi yang kurang akurat tersebut (1) Belum menyajikan "Peta Kompetensi" yang mengandung prinsip-prinsip yang digunakan siswa sebagai acuan untuk mencapai tujuan pembelajaran dan memahami materi pada masing-masing bab agar materi yang disampaikan dapat terstruktur dengan baik. (2) Penyajian contoh yang kurang relevan yang 
berkaitan dengan karakteristik latar belakang dan status sosial, adanya unsur sara, dan tidak sesuai kebutuhan. (3) Belum tersedia ilustrasi.

Abdulaziz, et al (2014) "Analisis Isi (Content Analysis) Buku Sekolah Elektronik (BSE) Pelajaran Pendidikan Jasmani Olahraga dan Kesehatan SMP Kelas VIII di Kota Semarang” hasil penelitian menunjukkan bhawa 1) kelayakan isi BSE penjasorkes buku 1 dan 2 termasuk dalam kategori sangat baik dan baik. Sedangkan hasil penelitian saya ditemukan penyajian materi yang kurang akurat dengan menggunakan teori Siagian (2015: 78) materi yang kurang akurat tersebut (1) Belum menyajikan "Peta Kompetensi" yang mengandung prinsip-prinsip yang digunakan siswa sebagai acuan untuk mencapai tujuan pembelajaran dan memahami materi pada masing-masing bab agar materi yang disampaikan dapat terstruktur dengan baik. (2) Penyajian contoh yang kurang relevan yang berkaitan dengan karakteristik latar belakang dan status sosial, adanya unsur sara, dan tidak sesuai kebutuhan. (3) Belum tersedia ilustrasi.

Basuki, et al (2015) yang meneliti "Analisis Isi Buku Ajar Bahasa Indonesia Wahan Penegtahuan Untuk SMP/MTs Kelas VIII” hasil analisis dari buku ajar, dapat disimpulkan bahwa: (1) buku ajar ini secara keseluruhan memiliki bagian-bagian yang harus ada pada buku ajar; (2) kesesuaian uraian materi pada buku ajar dengan KI dan KD mendapatkan persentase nilai 72,5\%, yang berarti buku ajar ini termasuk dalam kategori layak; (3) keakuratan materi pada buku ajar mendapatkan persentase nilai 93\%, yang berarti buku ajar ini termasuk dalam kategori sangat layak; (4) kelengkapan materi pendukung pembelajaran pada buku ajar mendapatkan persentase nilai 91\%, yang berarti buku ajar ini termasuk dalam kategori sangat layak; dan (5) buku ajar Bahasa Indonesia Wahana Pengetahuan untuk SMP/MTs kelas VIII dapat dikategorikan sebagai buku ajar dengan kualitas baik. Sedangkan hasil penelitian saya ditemukan penyajian materi yang kurang akurat dengan menggunakan teori Siagian (2015: 78) materi yang kurang akurat tersebut (1) Belum menyajikan "Peta Kompetensi" yang mengandung prinsip-prinsip yang digunakan siswa sebagai acuan untuk mencapai tujuan pembelajaran dan memahami materi pada masing-masing bab agar materi yang disampaikan dapat terstruktur dengan baik. (2) Penyajian contoh yang kurang relevan yang berkaitan dengan karakteristik latar belakang dan status sosial, adanya unsur sara, dan tidak sesuai kebutuhan. (3) Belum tersedia ilustrasi.

Pangestika, et al (2017) yang meneliti tentang "Kajian Buku Teks Bahasa Indonesia Tingkat Sekolah Menengah Pertama" hasil penelitian ini menyimpulkan bahwa: (1) kelayakan isi buku teks Bahasa Indonesia untuk SMP/MTs Kelas VII Edisi Revisi sudah baik ditandai dengan nilai rata-rata 38,14 (2) kelayakan bahasa buku teks Bahasa Indonesia untuk SMP/MTs KelasVII Edisi Revisi sudah baik ditandai dengan hasil penilaian dengan nilai rata-rata 19,24. Sedangkan hasil penelitian saya ditemukan penyajian materi yang kurang akurat dengan menggunakan teori Siagian (2015: 78) materi yang kurang akurat tersebut (1) Belum menyajikan "Peta Kompetensi" yang mengandung prinsip-prinsip yang digunakan siswa sebagai acuan untuk mencapai tujuan pembelajaran dan memahami materi pada masing-masing bab agar materi yang disampaikan dapat terstruktur dengan baik. (2) Penyajian contoh yang kurang relevan yang berkaitan dengan karakteristik latar belakang dan status sosial, adanya unsur sara, dan tidak sesuai kebutuhan. (3) Belum tersedia ilustrasi.

Supriyatun, et al (2017) yang meneliti "Kajian Buku Teks Pelajaran Bahasa Indonesia Untuk Kelas X Sekolah Menengah Atas Edisi Revisi 2016” dari analisis data dapat disimpulkan bahwa, (a) 
komponen penyajian sudah layak dengan total nilai 30,8 presentase $85,55 \%$, (b) kesesuaian uraian materi sudah layak dengan total nilai 6,75 presentase $84,37 \%$, (c) penggunaan bahasa sudah layak dengan total nilai 19,52 dengan presentase $81,34 \%$. Sedangkan hasil penelitian saya ditemukan penyajian materi yang kurang akurat dengan menggunakan teori Siagian (2015: 78) materi yang kurang akurat tersebut (1) Belum menyajikan "Peta Kompetensi" yang mengandung prinsip-prinsip yang digunakan siswa sebagai acuan untuk mencapai tujuan pembelajaran dan memahami materi pada masing-masing bab agar materi yang disampaikan dapat terstruktur dengan baik. (2) Penyajian contoh yang kurang relevan yang berkaitan dengan karakteristik latar belakang dan status sosial, adanya unsur sara, dan tidak sesuai kebutuhan. (3) Belum tersedia ilustrasi.

\section{PENUTUP}

\section{Simpulan}

Berdasarkan pemaparan di atas disimpulkan bahwa hasil analisis terhadap materi teks anekdot dan prosedur kompleks dalam buku teks Bahasa Indonesia SMA kelas X kurikulum 2013 karya Sobandi terbitan Erlangga, buku teks ini cukup layak digunakan sebagai bahan ajar untuk proses pembelajaran di sekolah-sekolah.

1. Akurasi konsep dan definisi dalam buku teks terbitan Erlangga yang dianalisis ini telah disajikan secara akurat, jelas, dan siswa dapat memahaminya dengan mudah, tidak membingungkan siswa sehingga tidak mengalami multitafsir.

2. Akurasi Prinsip dalam buku teks ini ditemukan penyajian prinsip yang kurang relevan karena karena belum menyajikan "Peta Kompetensi" yang mengandung prinsip-prinsip yang digunakan siswa sebagai acuan untuk mencapai tujuan pembelajaran dan memahami materi pada masing-masing bab agar materi yang disampaikan dapat terstruktur dengan baik.

3. Akurasi prosedur dalam materi teks anekdot dan prsedur kompleks dalam buku teks terbitan Erlangga ini, sesuai dengan karakteristik teks yang telah dipaparkan secara jelas dan runtut, sehingga dapat mempermudah siswa untuk memahami langkah-langkah menyusun teks anekdot dan prosedur kompleks.

4. Akurasi contoh, fakta, dan ilustrasi dalam buku teks terbitan Erlangga yang dianalisis ini telah disajikan dinilai kurang relevan dan akurat. Materi teks anekdot dan prsedur kompleks disajikan secara detail dan lengkap dalam buku teks Erlangga ini.

5. Akurasi Akurasi sosial dalam buku teks terbitan Erlangga yang dianalisis ini, telah disajikan materi yang ditunjang adanya aktivitas tugas individu yakni soal pilihan ganda dan soal esai yang dapat menunjang tingkat pemahaman siswa terhadap materi ini. 


\section{DAFTAR PUSTAKA}

Abdulaziz, et al. (2014). “Analisis Isi (Content Analysis) Buku Sekolah Elektronik (BSE) Pelajaran Pendidikan Jasmani Olahraga dan Kesehatan SMP Kelas VIII di Kota Semarang.” Journal of Physical Education and Sports, 3(1).

Bachri, Bachtiar S. 2010. "Meyakinkan Validitas Data Melalui Trianggulasi Pada Penelitian Kalitatif." Jurnal Teknologi Pendidikan, 10(1).

Banowati, Eva. 2007 . "Buku Teks Dalam Pembelajaran Geografi di Kota Semarang”. Jurnal Geografi, 4(2).

Basuki, Wulandayani Ngujer et al. (2015). “Analisis Isi Buku Ajar Bahasa Indonesia Wahana Pengetahuan Untuk SMP/MTs Kelas VIII”. BASASTRA Jurnal Penelitian Bahasa, Sastra Indonesia dan Pengajarannya, 3(2).

Hashemi, Seyede Zahra. (2012). “Textbook Evaluation: An Investigation into Touchstone Series.” Theory and Practice in Language Studies, 2(12).

Jatmika, Herka Maya. (2014). ”Analisis Kelayakan Isi BukuTeks Penjesorkes Kelas X SMA di Kabupaten Bantul Daerah Istimewa Yogyakarta”. Jurnal Pendidikan Jasmani Indonesia, 10(2).

Kraenbring, et al. (2014). "Accuracy and Completeness of Drug Information in Wikipedia: A Comparison with Standard Textbooks of Pharmacolog”. Analysis of Curricular Drug Information in Wikipedia, 9.

Muslich, Mansur. (2010). Text Book Writing. Jakarta: Ar-Rus Media.

Muslimin. (2011). “Analisis Buku Teks Bahasa Indonesia Untuk Smp Kelas Ix Dengan Pendekatan Tematik.” Jurnal Bahasa, Sastra, \& Budaya, 1(2).

Nonaka, et al. (2012). "Content Analysis of Primary and Secondary School Textbooks Regarding Malaria Control: A Multi-Country Study”. PLoS ONE, 7.

Nurmutia, et al. (2013). “Analisis Materi, Penyajian, dan Bahasa Buku Teks Matematika SMA Kelas X di Kabupaten Rembang”. Unnes Journal of Mathematics Education, 2(3).

Pangestika, Dyaning Nidya et al. (2017). "Kajian Buku Teks Bahasa Indonesia Tingkat Sekolah Menengah Pertama”. BASASTRA Jurnal Penelitian Bahasa, Sastra Indonesia dan Pengajarannya, 5(2). 
Rahmawati,Nurul Laili et al. (2013). "Pengembangan Buku Saku IPA Terpadu Bilingual Dengan Tema Bahan Kimia Dalam Kehidupan Sebagai Bahan Ajar Di MTs". Unnes Science Education Journal, 2(1).

Rohmadi, Muhammad dan Yakub Nasucha. (2017). Dasar-dasar Penelitian Bahasa, Sastra, dan Pengajarannya. Surakarta: Pustaka Briliant.

Roy-Charland1, Annie, Melanie Perron1, Krystle-Lee Turgeon1, N. H., \& Chamberland1, J. A. (2016). "The link between text difficulty, reading speed and exploration of printed text during shared book reading.” Springer Science+Business Media Dordrecht, 29, 731-743.

Rumat, Vience Mutiara. 2017. “Analisis Isi Kualitatif Twitter '\#Taxamnesty’ Dan '\#Amnestipajak.' JURNAL PIKOM (Penelitian Komunikasi dan Pembangunan), 18(1).

Siagian, Beslina Afriani. 2016. “Analisis Kesesuaian Isi Buku Teks Bahasa Indonesia Berbasis Kurikulum 2013”. JURNAL Suluh Pendidikan FKIP-UHN, 3(1).

Sitepu. 2012. Penulisan Buku Teks Pelajaran. Bandung: PT Remaja Rosdakarya.

Supriyatun, et al. 2017. "Kajian Buku Teks Pelajaran Bahasa Indonesia Untuk Kelas X Sekolah Menengah Atas Edisi Revisi 2016”. Jurnal Penelitian Bahasa, Sastra Indonesia dan Pengajarannya, 5(2).

Tarigan, Henry Guntur. 2009. Telaah Buku Teks Bahasa Indonesia. Bandung: Angkasa.

Widodo, Handoyo Puji. 2007. “Texbook Analiysis On Collage Academic Writing”. TELFIN Journal, 18(2).

Yanti, Yuli. 2016. “Analisis Buku Ajar Fikih Kelas VI (Studi Komparasi di MI Sultan Agung dan SD IT Ar- Rohmah)". Jurnal Pendidikan dan Pembelajaran Dasar, 3(1).

Yusfiani, Mamida dan Manihar Situmorang. 2011. "Pengembangan dan Standarisasi Buku Ajar Kimia SMA/SMK Kelas XII Semester I Berdasarkan Standar Isi KTSP”. Jurnal Penelitian Bidang Pendidikan, 17(1). 